EGU2020-22655, updated on 15 May 2020

https://doi.org/10.5194/egusphere-egu2020-22655

EGU General Assembly 2020

(c) Author(s) 2020. This work is distributed under

the Creative Commons Attribution 4.0 License.

\title{
Hydrodynamic and hydrochemical evolution of the Bajo Guadalhorce Valley alluvial aquifer (Málaga, S Spain) in the last 40 years
}

José Manuel Nieto López, Juan Antonio Barberá Fornell, and Bartolomé Andreo Navarro Department of Geology and Centre of Hydrogeology of the University of Málaga (Spain). Boulevar Louis Pasteur, s/n.

Campus de Teatinos, 29010

Groundwater flowing through coastal aquifers is increasingly impacted by human pressures as consequence of a growing demand on drinking water, tourism and agriculture, among others. Thus, groundwater availability very often depend on its quality since water salinization and pollution are the main challenges for water management because of seawater and freshwater interaction. Therefore, it is crucial to monitor the availability of groundwater and its quality under changing scenarios where this water resource can be specially threatened.

This study aims to assess the spatial distribution and time evolution of groundwater levels and hydrochemistry of the alluvial aquifer of the Bajo Guadalhorce Valley (Málaga, S Spain) for the evaluation of its quantitative and qualitative status. To that, groundwater level, electrical conductivity and $\mathrm{Cl}^{-}$and $\mathrm{SO}_{4}{ }^{2-}$ concentrations of water have been measured in a field sampling campaign carried out in the alluvial aquifer of the Bajo Guadalhorce Valley (Málaga, S Spain) in April 2017. Additionally, historical data from the last 40 years have been compiled.

Results show that groundwater generally flow towards the Guadalhorce River, where gaining relationship remains more patent in its lower river stretch, and the Mediterranean Sea. Some negative groundwater elevations close to the coastal fringe are observed in several piezometers because of pumping during the study period. Electrical conductivity values were, generally, lower than $4 \mathrm{mS} / \mathrm{cm}$ in all samples and the major changes in groundwater mineralization were determined in the Guadalhorce River Mouth. In this aquifer sector, substantial increases in groundwater mineralization were identified, up to 50\% in some observation points. $\mathrm{Cl}^{-}$and $\mathrm{SO}_{4}{ }^{2-}$ concentrations in groundwater (the more concentrated solutes of all) evolve similarly in time to that of electrical conductivity, with maximum recorded values up to $10000 \mathrm{mg} / \mathrm{l}$ and $2000 \mathrm{mg} / \mathrm{l}$, respectively, the coastal area in 2017.

Changes in $\mathrm{EC}$ and $\mathrm{Cl}^{-}$and $\mathrm{SO}_{4}{ }^{2-}$ concentrations in the river mouth area could be related to the land use changes that took place here between 1997 and 2003, where channelization works resulted in the splitting of the river in two branches. This could have affected to the aquifer hydrodynamics, due to the reduced groundwater discharge to the river mouth area between both branches. This could have favored the mixing among surface water, sea water and groundwater. 
Also, the urbanized area has increased over the years, reducing the recharge area of this part of the aquifer, but also flowing groundwater has increased because of pumping reduction (up to 7 $\mathrm{hm}^{3}$ /year). The presence of $\mathrm{Cl}^{-}$in the aquifer, as well as $\mathrm{SO}_{4}{ }^{2-}$, is due to evaporite dissolution and the interaction with the Mediterranean Sea in the coastal area. An extra input of $\mathrm{SO}_{4}{ }^{2-}$ comes from of the fertilizers used in agriculture.

The availability of long-term hydrogeological data in a coastal aquifer (1976-2017) has allowed to check a remarkable salinization in the coastal area, caused by land use modifications. So, the monitoring of hydrogeological data is a very important tool to be used by land managers in coastal aquifers, where groundwater can be seriously endangered by human activities. 